\title{
Commentary - Early discontinuation of antiseizure medication in neonatal seizures - Proceed with caution
}

\author{
J.J. Volpe $\mathrm{a}^{\mathrm{a}, \mathrm{b}, *}$ \\ ${ }^{a}$ Department of Neurology, Harvard Medical School, Boston, MA, USA \\ ${ }^{\mathrm{b}}$ Department of Pediatric Newborn Medicine, Harvard Medical School, Boston, MA, USA
}

Received 21 July 2021

Accepted 7 August 2021

Keywords: Neonatal seizures, antiseizure medication, early discontinuation

\section{Introduction}

The issue of when to stop antiseizure medication (ASM) in a newborn with acute symptomatic seizures (seizures occurring in the neonatal period and related to an acute brain insult) is of particular importance for two major reasons. Firstly, ASM may be harmful to the brain of the newborn (see later). Secondly, however, seizures per se also may be harmful to the neonatal brain (see later). ASM often has been continued for several months to prevent seizure-related brain injury, including epilepsy, and impaired developmental outcome. In 2011, after detailed study by an international group of experts, a WHO guideline recommended "in neonates with normal neurological examination and/or normal electroencephalography, consider stopping anti-epileptic drugs if seizure-free for $>72$ hours" [1]. "Seizure-free" was defined as absence of seizures on continuous EEG.

\footnotetext{
*Address for correspondence: Joseph J. Volpe, M.D. Department of Pediatric Newborn Medicine, Brigham and Women's Hospital, 221 Longwood Avenue, Room 343C, Boston, MA 02115, USA. Tel.: +1 617525 4145; E-mail: Joseph.volpe@ childrens.harvard.edu.
}

Stimulated by studies from small and single-center studies supporting the notion that early ASM discontinuation for acute seizures is not harmful [2-4], a prospective, observational, multicenter study at 9 centers of infants with acute symptomatic neonatal seizures, born between July 2015 and March 2018, was carried out [5]. A total of 305 infants, primarily $(84 \%)$ term born, were studied. The etiologies of the seizures were principally hypoxic-ischemic encephalopathy (43\%) and ischemic stroke (26\%). In contrast to the WHO recommendations, seizure resolution was defined as only 24 hours free of seizures, and ASM (principally phenobarbital) was discontinued in some even in the setting of abnormal EEG and neurological examination. Among the 270 infants evaluated at 24 months, neurodevelopmental outcome and risk of epilepsy were similar in those in whom ASM was discontinued or maintained at discharge. The authors concluded that their results support "routine discontinuation of ASM after resolution of acute symptomatic neonatal seizures prior to hospital discharge" [5].

The purpose of this commentary is to suggest that the term "routine discontinuation" is too broad and to encourage the neonatologist to evaluate each infant 
individually and, in particular, to consider (1) the neurological disorder causing the seizures, especially the results of brain imaging, (2) the near-discharge neurological examination, and (3) the near-discharge EEG (see later).

\section{Deleterious effects of seizures and ASM on the developing brain}

Central to the issues of duration of seizure treatment with ASMs are two questions; 1) do seizures cause and/or accentuate neonatal brain injury, i.e., are seizures harmful, and 2) do the interventions to treat neonatal seizures, ASMs, have deleterious effects on the developing brain. Each of these issues is discussed briefly next (for detailed review see [6, 7]).

Experimental and clinical data support the conclusion that recurrent seizures can cause and/or accentuate neonatal brain injury. The newborn infant has a propensity to develop recurrent seizures and neuronal injury in considerable part because of a concentration of excitatory amino acid receptors on neurons of cerebral cortex $[8,9]$. When excessively activated, these receptors lead to enhanced $\mathrm{Ca}^{++}$ influx, generation of free radicals and cell death. In particular, these receptors have molecular properties that render them more excitable than receptors on mature neurons [10-16]. Moreover, GABA receptors on perinatal neurons are excitatory rather than inhibitory, as in mature brain [6]. This paradox occurs because GABA receptor activation results in $\mathrm{Cl}^{-}$ efflux and depolarization (excitation) rather than the $\mathrm{Cl}^{-}$influx and hyperpolarization (inhibition) that occur on mature GABAergic neurons. The reason for this phenomenon is that neuronal $\mathrm{Cl}^{-}$levels are abnormally high in immature cortex because of a developmental imbalance between the two $\mathrm{Cl}^{-}$transporters that determine neuronal $\mathrm{Cl}^{-}$levels $[6,17]$.

Concerning the relation of recurrent neonatal seizures to later epilepsy and impaired neurodevelopment, in animal models of recurrent neonatal seizures, long-term changes in these receptors and transporters can occur and predispose to subsequent spontaneous seizure activity [18-22]. Importantly, these long-term changes could be reversed by targeted therapies. The data support the notion that early post-seizure treatment may mitigate some of the deleterious long-term consequences of neonatal seizures, particularly the later development of epilepsy [6]. In other experimental studies, the principal anatomic correlates of recurrent seizures have included synaptic reorganization of axons and terminals in hippocampus, dendritic spine loss in hippocampus, and impaired hippocampal dentate granule cell neurogenesis $[14,23]$. The functional correlates have been deficits in cognition. An additional role of neuronal death secondary to excessive $\mathrm{Ca}^{++}$influx (see earlier) in the genesis of the functional deficits is likely.

Clinical studies have supported the notion that increased neonatal seizures are associated with worse brain injury, later epilepsy and less favorable overall neurological outcome. Studies that have utilized MRI have shown increased neonatal seizure burden to be associated with more severe MRI brain injury [24-28] and worse neurological outcome [24, 26, 28-33]. Nearly all the infants studied had hypoxic-ischemic encephalopathy and were studied both before and after the advent of treatment with hypothermia. The obvious difficulty in such studies is distinguishing whether greater seizure occurrence was a biomarker of more severe injury or an important contribution to brain injury. Studies that have attempted to address this issue suggest that seizures are important contributors [24, 26-28, 31].

Taken together, the data described above suggest that in the human infant, as in experimental models, recurrent seizures in the newborn are deleterious to brain and should be treated sufficiently aggressively to eliminate the seizure activity. Whether the goal should be discontinuation of EEG seizure activity after only 24 hours, as in the study of Glass et al. [5], or for 72 hours, as recommended by the WHO group [1], is not clear. The former interval is recommended by the American Clinical Neurophysiology Society [34].

Concerning deleterious effects of ASMs, the most relevant drug to consider is phenobarbital, since this agent is by far the most widely used ASM. The question of a deleterious effect of phenobarbital on the developing brain was raised by earlier data obtained with rats and cultured neural cells [35-39]. However, the relation of these data to human infants is unclear, largely because the duration of therapy corresponded to a period in the human from approximately the sixth month of gestation to years postnatal. Perhaps more concerning are studies in neonatal rats that showed pronounced apoptotic neurodegeneration within 24 hours after administration of phenobarbital [40, 41]. The neuronal death was associated with reduced expression of neurotrophins and survival-promoting proteins in brain. Recent experimental studies also show disturbances of synaptic 
development in striatum [42] and GABAergic maturation in hippocampus [43]. However, some clinical data show that phenobarbital-related reduction in neonatal seizures is associated with more favorable neurological outcomes [6] (see earlier), Moreover, the frequently cited study that chronic use of phenobarbital in infants with febrile seizures results in lower IQ [44] does not appear clearly relevant to the newborn and very young infant, because the children were older and treated for 2 years. Thus, at present, the use of phenobarbital in conventional doses and over relatively short periods has not been proven to be deleterious.

\section{Think twice before ASM discontinuation}

The optimal duration of ASM therapy for newborns with seizures relates principally to the likelihood of seizure recurrence if the drugs are discontinued. This issue has been discussed in detail elsewhere [6] and is beyond the scope of this commentary. However, three features deserve emphasis here, i.e., (1) the etiology and characteristics of the brain injury causing the seizures, (2) the neurological exam at discharge, and (3) the EEG near discharge.

Concerning the brain injury underlying the neonatal seizures, hypoxic-ischemic encephalopathy and ischemic stroke, the two etiologies that accounted for $70 \%$ of all infants with seizures in the study of Glass et al. [5] have different risks for subsequent epilepsy according to the topography of injury. In hypoxic-ischemic encephalopathy treated with hypothermia, recent studies indicate an overall risk of long-term epilepsy to be approximately 15-20\% [45-47]. However, risk is increased considerably with involvement of deep nuclear structures (thalamus, basal ganglia) and of watershed regions of cerebral cortex.

In ischemic stroke, the risk of subsequent epilepsy is approximately 20-40\% [48, 49]. Factors most predictive of subsequent epilepsy are involvement of the main branch of the middle cerebral artery and especially cerebral cortex within its distribution; involvement of thalamus or of temporal lobe also are predictive of subsequent epilepsy. A reflection of the concern for subsequent epilepsy in infants with stroke in the study of Glass et al. is the fact that $72 \%$ of the infants with stroke in the nine Centers were maintained on ASM after discharge [5]. Indeed, only 22 infants with stroke involved in the study had ASM discontinued. This small number renders the comparative data concerning outcomes in the stroke group seriously underpowered.

The results of the neurological examination at discharge can be useful [6]. In older studies of infants with seizures secondary to HIE, those with normal neurological findings at discharge did not develop subsequent recurrent seizures. However, more data are needed on this issue, especially utilizing a systematic quantitative assessment of the neurological exam. In the study of Glass et al. an abnormal neurological exam at discharge was reported to be no different than a normal exam in prediction of subsequent seizures [5]. However, notably, as with stroke the number of infants with an abnormal neurological examination who had ASM discontinued in the nine Centers was relatively small. Thus, only approximately $20 \%$ $(n=20)$ of such infants had ASM discontinued, and thus the conclusion that abnormal neurological examination at discharge should not influence the decision to discontinue is based on the results of a relatively small number of infants.

The results of at least 24 hours of continuous EEG are also of predictive value for subsequent epilepsy. Detailed consideration of this issue is available elsewhere [6, 50-55]. Infants at enhanced risk of subsequent epilepsy include those with burstsuppression pattern or marked overall depression. Some consider the 24-hour seizure-free interval as sufficient to discontinue ASM to be too brief. The WHO recommendation is to consider stopping ASM if the EEG seizure-free interval is 72 hours [1]. Additionally, detailed analysis of outcomes of infants with recurrent runs of sharp waves or spikes that do not reach the 10-second definition of seizure but in whom ASM was discontinued is not available, but such EEG features should give the physician pause concerning discontinuation of phenobarbital.

These three factors should be assessed again on early follow-up. It is beyond the scope of this Commentary to address timing of discontinuation of ASM beyond the neonatal period. In general, reassessment after 1-3 months is appropriate. Prolonged treatment of ASM in infancy should be avoided whenever possible.

The central point is that the neonatologist should consider the totality of the infant's structural and functional neurological status before discontinuing ASM in the neonatal period. The decision to discontinue is not a simple one and should not be characterized as "routine". Nevertheless, the study by Glass et al. is a very important beginning to address this issue. Indeed, their data suggest that many infants 
with seizures need not be maintained on ASM beyond the neonatal period. However, as the authors indicate in their conclusion, "larger longer-term studies are needed" [5].

\section{References}

[1] Guidelines on neonatal seizures. Geneva: World Health Organization; 2011.

[2] Hellstrom-Westas L, Blennow G, Lindroth M, Rosen I, Svenningsen NW. Low risk of seizure recurrence after early withdrawal of antiepileptic treatment in the neonatal period. Arch Dis Child Fetal Neonatal Ed. 1995;72:F97-101.

[3] Guillet R, Kwon J. Seizure recurrence and developmental disabilities after neonatal seizures: Outcomes are unrelated to use of phenobarbital prophylaxis. J Child Neurol. 2007;22:389-95.

[4] Fitzgerald MP, Kessler SK, Abend NS. Early discontinuation of antiseizure medications in neonates with hypoxicischemic encephalopathy. Epilepsia. 2017;58:1047-53.

[5] Glass HC, Soul JS, Chang T, Wusthoff CJ, Chu CJ, Massey SL, et al. Safety of early discontinuation of antiseizure medication after acute symptomatic neonatal seizures. JAMA Neurol. 2021.

[6] Abend NS, Jensen FE, Inder TE, Volpe JJ. Neonatal seizures. In: Volpe JJ, Inder TE, Darras BT, deVries LS, duPlessis AJ, Neil JJ, et al., editors. Volpe's Neurology of the Newborn. Chapter 12, 6th ed. Philadelphia: Elsevier; 2018. pp. 275-321.

[7] Volpe JJ. Neonatal seizures. Neurology of the newborn. Chapter 5, 5th ed. Philadelphia: Elsevier; 2008. pp. 203-44.

[8] Jantzie LL, Talos DM, Jackson MC, Park HK, Graham DA, Lechpammer $\mathrm{M}$, et al. Developmental expression of N-methyl-D-aspartate (NMDA) receptor subunits in human white and gray matter: Potential mechanism of increased vulnerability in the immature brain. Cereb Cortex. 2015;25:482-95.

[9] Talos DM, Follett PL, Folkerth RD, Fishman RE, Trachtenberg FL, Volpe JJ, et al. Developmental regulation of alpha-amino-3-hydroxy-5-methyl-4-isoxazolepropionic acid receptor subunit expression in forebrain and relationship to regional susceptibility to hypoxic/ischemic injury. II. Human cerebral white matter and cortex. J Comp Neurol. 2006;497:61-77.

[10] Villeneuve N, Ben-Ari Y, Holmes GL, Gaiarsa J-L. Neonatal seizures induced persistent changes in intrinsic properties of CA1 rat hippocampal cells. Ann Neurol. 2000;47:729-38.

[11] Sanchez RM, Koh S, Rio C, Wang C, Lamperti ED, Sharma D, et al. Decreased glutamate receptor 2 expression and enhanced epileptogenesis in immature rat hippocampus after perinatal hypoxia-induced seizures. J Neurosci. 2001;21:8154-63.

[12] Koh S, Tibayan FD, Simpson JN, Jensen TE. NBQX or topiramate treatment after perinatal hypoxia-induced seizures prevents later increases in seizure-induced neuronal injury. Epilepsia. 2004;45:569-75.

[13] Sanchez RM, Dai WM, Levada RE, Lippman JJ, Jensen FE. AMPA/kainate receptor-mediated downregulation of GABAergic synaptic transmission by calcineurin after seizures in the developing rat brain. J Neurosci. 2005;25: $3442-51$.
[14] Holmes GL. Effects of seizures on brain development: Lessons from the laboratory. Pediatr Neurol. 2005;33:1-11.

[15] Sanchez RM, Jensen FE. Modeling hypoxia-induced seizures and hypoxic encephalopathy in the neonatal period. In: Pitanken A, Schwartzkroin PA, Moshe SL, editors. Models of Seizures and Epilepsy. San Diego: Elsevier Press; 2006.

[16] Holmes GL, Ben-Ari Y. A single episode of neonatal seizures permanently alters glutamatergic synapses. Ann Neurol. 2007;61:379-81.

[17] Dzhala VI, Talos DM, Sdrulla DA, Brumback AC, Mathews GC, Benke TA, et al. NKCC1 transporter facilitates seizures in the developing brain. Nat Med. 2005;11:1205-13.

[18] Kadam SD, Dudek FE. Neuropathogical features of a rat model for perinatal hypoxic-ischemic encephalopathy with associated epilepsy. J Comp Neurol. 2007;505:716-37.

[19] Rakhade SN, Klein PM, Huynh T, Hilario-Gomez C, Kosaras B, Rotenberg A, et al. Development of later life spontaneous seizures in a rodent model of hypoxia-induced neonatal seizures. Epilepsia. 2011;52:753-65.

[20] Rakhade SN, Fitzgerald EF, Klein PM, Zhou C, Sun H, Huganir RL, et al. Glutamate receptor 1 phosphorylation at serine 831 and 845 modulates seizure susceptibility and hippocampal hyperexcitability after early life seizures. J Neurosci. 2012;32:17800-12.

[21] Lippman-Bell JJ, Rakhade SN, Klein PM, Obeid M, Jackson MC, Joseph A, et al. AMPA receptor antagonist NBQX attenuates later-life epileptic seizures and autisticlike social deficits following neonatal seizures. Epilepsia. 2013;54:1922-32.

[22] Sun H, Juul HM, Jensen FE. Models of hypoxia and ischemia-induced seizures. J Neurosci Methods. 2016;260: 252-60.

[23] Sogawa Y, Monokoshi M, Silveira DC, Cha BH, Cilio MR, McCabe BK, et al. Timing of cognitive deficits following neonatal seizures: Relationship to histological changes in the hippocampus. Dev Brain Res. 2001;131:73-83.

[24] Glass HC, Glidden D, Jeremy RJ, Barkovich AJ, Ferriero DM, Miller SP. Clinical neonatal seizures are independently associated with outcome in infants at risk for hypoxicischemic brain injury. J Pediatr. 2009;155:318-23.

[25] van Rooij LG, Toet MC, van Huffelen AC, Groenendaal F, Laan W, Zecic A, et al. Effect of treatment of subclinical neonatal seizures detected with aEEG: Randomized, controlled trial. Pediatrics. 2010;125:e358-66.

[26] Shah DK, Wusthoff CJ, Clarke P, Wyatt JS, Ramaiah $\mathrm{SM}$, Dias RJ, et al. Electrographic seizures are associated with brain injury in newborns undergoing therapeutic hypothermia. Arch Dis Child Fetal Neonatal Ed. 2014;99: F219-24.

[27] Srinivasakumar P, Zempel J, Trivedi S, Wallendorf M, Rao $\mathrm{R}$, Smith $\mathrm{B}$, et al. Treating EEG seizures in hypoxic ischemic encephalopathy: A randomized controlled trial. Pediatrics. 2015;136:e1302-9.

[28] Dunne JM, Wertheim D, Clarke P, Kapellou O, Chisholm P, Boardman JP, et al. Automated electroencephalographic discontinuity in cooled newborns predicts cerebral MRI and neurodevelopmental outcome. Arch Dis Child Fetal Neonatal Ed. 2017;102:F58-F64.

[29] McBride MC, Laroia N, Guillet R. Electrographic seizures in neonates correlate with poor neurodevelopmental outcome. Neurology. 2000;55:506-13.

[30] van Rooij LG, de Vries LS, Handryastuti S, Hawani D, Groenendaal F, van Huffelen AC, et al. Neurodevelopmental outcome in term infants with status epilepticus detected 
with amplitude-integrated electroencephalography. Pediatrics. 2007;120:e354-63.

[31] Meyn DF, Jr., Ness J, Ambalavanan N, Carlo WA. Prophylactic phenobarbital and whole-body cooling for neonatal hypoxic-ischemic encephalopathy. J Pediatr. 2010;157: 334-6.

[32] Painter MJ, Sun Q, Scher MS, Janosky J, Alvin J. Neonates with seizures: What predicts development? J Child Neurol. 2012;27:1022-6.

[33] Maartens IA, Wassenberg T, Buijs J, Bok L, de Kleine MJ, Katgert T, et al. Neurodevelopmental outcome in full-term newborns with refractory neonatal seizures. Acta Paediatr. 2012;101:e173-8

[34] Shellhaas RA, Chang T, Tsuchida T, Scher MS, Riviello JJ, Abend NS, et al. The American Clinical Neurophysiology Society's Guideline on continuous electroencephalography monitoring in neonates. J Clin Neurophysiol. 2011;28: 611-7.

[35] Diaz J, Schain RJ, Bailey BG. Phenobarbital-induced brain growth retardation in artificially reared rat pups. Biol Neonate. 1977;32:77-82.

[36] Diaz J, Schain RJ. Phenobarbital: effects of long-term administration on behavior and brain of artificially reared rats. Science. 1978;199:90.

[37] Neale EA, Sher PK, Graubard BI, Habig WH, Fitzgerald SC, Nelson PG. Differential toxicity of chronic exposure to phenytoin, phenobarbital, or carbamazepine in cerebral cortical cell cultures. Pediatr Neurol. 1985;1:143-50.

[38] Serrano EE, Kunis DM, Ransom BR. Effects of chronic phenobarbital exposure on cultured mouse spinal cord neurons. Ann Neurol. 1988;24:429-38.

[39] Swaiman KF, Machen VL. Effects of phenobarbital and phenytoin on cortical glial cells in culture. Brain Dev. 1991;13:242-6.

[40] Bittigau P, Sifringer M, Genz K, Reith E, Pospischil D, Govindarajalu S, et al. Antiepileptic drugs and apoptotic neurodegeneration in the developing brain. Proc Natl Acad Sci USA. 2002;99:15089-94.

[41] Bittigau P, Sifringer M, Ikonomidou C. Antiepileptic drugs and apoptosis in the developing brain. Ann NY Acad Sci. 2003;993:103-14.

[42] Forcelli PA, Janssen MJ, Vincini S, Gale K. Neonatal exposure to antiepileptic drugs disrupts striatal development. Ann Neurol. 2012;72:363-72.

[43] Al-Muhtasib N, Sepulvida-Rodriques A, Vincini S, Forcelli PA. Neonatal phenobarbital exposure disrupts GABAergic symaptic maturation in rat CA1 neurons. Epilepsia. 2018;59:333-44..
[44] Farwell JR, Lee YJ, Hirtz DG, Sulzbacher SI, Ellenberg JH, Nelson KB. Phenobarbital for febrile seizures-effects on intelligence and on seizure recurrence. N Engl J Med. 1990;322:364-9.

[45] Jung DE, Ritacco DG, Nordi DR, Koh S, Venkatesan C. Early anatomical injury patterns predict epilepsy in head cooled neonates with hypoxic-ischemic encephalopathy. Pediatr Neurol. 2015;53:135-40.

[46] McDonough TL, Paolicchi JM, Heier LA, Das N, Engel M, Perlman JM, et al. Prediction of future epilepsy in neonates with hypoxic-ischemic encephalopathy who received selective head cooling. J Child Neurol. 2017;32:630-7.

[47] Xu Q, Chau V, Sanguansermsri C, Muir KE, Tam EWY, Miller SP, et al. Pattern of Brain Injury Predicts Long-Term Epilepsy Following Neonatal Encephalopathy. J Child Neurol. 2019;34:199-209.

[48] Laugesaar R, Kolk A, Tomberg T, Metsvaht T, Lintrop M, Varendi $\mathrm{H}$, et al. Acutely and retrospectively diagnosed perinatal stroke: A population-based study. Stroke. 2007; 38:2234-40.

[49] Inder TE, Volpe JJ. Stroke in the newborn. In: Volpe JJ IT, Darras BT, deVries LS, DuPlessis AJ, Neil JJ, Perlman JM, editor. Volpe's Neurology of the Newborn. Chapter 21, 6th ed. Philadelphia, PA: Elsevier; 2018. pp. 564-89.

[50] Corsellis JAN, Meldrum BS. Epilepsy. In: Blackwood W, Corsellis JAN, editors. Greenfield's Neuropathology. London: Edward Arnold; 1976. pp. 971.

[51] Volpe JJ. Neurology of the newborn. 5th ed. Philadelphia: Elsevier; 2008.

[52] Watanabe K, Hara K, Miyazaki S, Hakamada S, Kuroyanagi M. Apneic seizures in the newborn. Am J Dis Child. 1982;136:980-4.

[53] Brod SA, Ment LR, Ehrenkranz RA, Bridgers S. Predictors of success for drug discontinuation following neonatal seizures. Pediatr Neurol. 1988;4:13-7.

[54] Ortibus EL, Sum JM, Hahn JS. Predictive value of EEG for outcome and epilepsy following neonatal seizures. Electroencephalog Clin Neurophysiol. 1996;98:175-85.

[55] Toet MC, Groenendaal F, Osredkar D, van Huffelen AC, de Vries LS. Postneonatal epilepsy following amplitudeintegrated EEG-detected neonatal seizures. Pediatr Neurol. 2005;32:241-7. 